\title{
Influence of Water Storage Time on the Bond Strength of Etch-and-Rinse and Self-Etching Adhesive Systems
}

\author{
Darlene Cristina Ramos Eloy DANTAS ${ }^{1}$ \\ Ana Isabella Arruda Meira RIBEIRO ${ }^{1,2}$ \\ Lúcia Helena Marques de Almeida LIMA ${ }^{1}$ \\ Marcelino Guedes de LIMA ${ }^{1}$ \\ Gymenna Maria Tenório GUÊNES ${ }^{1,2}$ \\ Ana Karla Souza BRAZ ${ }^{2}$ \\ Rodivan BRAZ ${ }^{2}$ \\ ${ }^{1}$ Department of Dentistry, State University of Paraíba, Campina Grande, PB, Brazil \\ ${ }^{2}$ Department of Restorative Dentistry, Dental School of Pernambuco, Camaragibe, PE, Brazil
}

\begin{abstract}
The purpose of this study was to evaluate comparatively the shear bond strength (SBS) of etch-and-rinse (Adper Scotch Bond Multi Purpose - ASBMP and Adper Single Bond 2 - ASB2) and self-etching (AdheSe -AD and Adper Prompt - AP) adhesive systems after short- and long-term water storage. Eighty bovine teeth were randomly assigned to 4 groups (n=20, 10 teeth for $24 \mathrm{~h}$ and 10 for 6 months). After surface treatment, composite resin cylinders were made with Tetric Ceram using a bisected metallic matrix. The specimens were stored in distilled water at $37^{\circ} \mathrm{C}$ for either $24 \mathrm{~h}$ or 6 months. After these periods, shear strength was assessed in a universal testing machine $(0.5 \mathrm{~mm} / \mathrm{min})$. Data were submitted to ANOVA and F test at $5 \%$ significance level. Mean SBSs (MPa) for $\operatorname{ASBMP}(10.03 \pm 3.78)$ and ASB2 $(6.10 \pm 2.67)$ showed no statistically significant differences $(\mathrm{p}>0.05)$ between times. The selfetching systems did not differ significantly from each other within the 24-h period, but significant difference was found for AD (1.37 \pm 0.64 ) after 6 months of water storage. In conclusion, the tested etch-and-rinse systems had a better performance in terms of bond durability over time than the self-etching systems.
\end{abstract}

Key Words: water storage, shear bond strength, dentin adhesive.

\section{INTRODUCTION}

Bonding to dental substrate can be obtained by means of three different strategies: total etch, selfetching or the bond strategy using ionomer glass cement (1). Adhesive systems are available as three-, two- and one-step materials, depending on how the etching, priming and bonding phases are performed (2). Selfetching systems have been developed with the aim of eliminating phosphoric acid etching and reducing the number of steps during the restorative procedure (3). However, in spite of the advances of self-etching adhesive systems, a lasting bond is still a challenge to
Dentistry (4). The artifices used to simplify the selfetching adhesive technique may become self-limiting factors of their durability.

The great majority of in vitro tests are performed within $24 \mathrm{~h}$ following the tooth-adhesive-resin composite bonding procedure (5). These immediate tests, although well established in the literature (6), do not consider bond degradation over time. The 24-hour time interval is adequate for testing the adhesive ability, but fails to provide information concerning the changes occurring on a long-term basis. Laboratory studies investigating the long-term durability of the adhesive interface are important because failures in its bond 
strength contribute to the destruction of the collagen network due to hydrolysis. Water is ubiquitous in the mouths of healthy individuals and routinely interferes with efforts to bond restorations to dental tissues. (7) Microleakage at the tooth-adhesive interface is another important factor to be considered as far as bond longterm durability of is concerned (8). The presence of demineralized zones not infiltrated or poorly infiltrated by the resin monomers has recently been attributed to the occurrence of the nanoleakage phenomenon (9), which is directly related to permeability of the adhesive system. It is possible to observe the hydrophilic sites of these materials, which are represented by thin channels left by the passage of water during the phenomenon of adhesive permeability, providing morphological evidence of fluid permeation through these adhesives, which follow ramification patterns similar to those found in trees, and for this reason are called water-trees (10).

The effect of water on the degradation process of adhesive systems is remarkable, since its capacity to permeate the polymerized adhesive is directly related to its hydrophilic characteristic. Because of this, adhesive systems become more susceptible to water absorption, capable to accelerate the hydrolytic degradation in the course of time (9).

Considering the development of current adhesive systems, particularly with regard to the simplification of recent formulations, it is extremely important to assess the stability of the tooth-adhesive-resin interface, when restorations are submitted to storage in a degrading medium. This study tested the null hypothesis that self- etching and etch-and-rinse adhesive systems have the same behavior when stored in a degrading medium. The purpose was to evaluate comparatively the shear bond strength (SBS) of etch-and-rinse and self-etching adhesive systems after short- and long-term water storage.

\section{MATERIAL AND METHODS}

Eighty sound bovine incisors were cleaned of gross debris and stored in distilled water at $4^{\circ} \mathrm{C}$, replaced weekly, for the maximum storage period of 6 months until the experiment started. All roots were sectioned transversally with water-cooled double-faced diamond disks (KG Sorensen, São Paulo, SP, Brazil).

The crowns were individually embedded in acrylic resin (Jet Classico, São Paulo, SP, Brazil) using PVC cylinders as molds ( $2 \mathrm{~cm}$ diameter; $1 \mathrm{~cm}$ height) and ground wet with 180- to 320-grit sandpapers (Carborundum Abrasivos, Recife, PE, Brazil) until a flat dentin surface was obtained. The tested materials with their compositions, specifications and manufacturers are given on Table 1 . The specimens were randomly assigned to 8 groups ( $n=10$ ), according to the etch-andrinse (Adper Scotch Bond Multi Purpose - ASBMP and Adper Single Bond 2- ASB2) and self-etching (AdheSe -AD and Adper Prompt - AP) and storage times - shortterm (24 h) and long-term (6 months).

The adhesive systems were applied according to the manufacturers' instructions. Dentin surface were coated with Tetric Ceram (Ivoclar/Vivadent, Shaan, Liechtenstein) composite resin forming a cylinder (6

Table 1. Adhesive systems.

\begin{tabular}{lcc}
\hline Material & Composition* & Batch number \\
\hline $\begin{array}{l}\text { Adper ScotchBond } \\
\text { Multi Purpose** }\end{array}$ & $\begin{array}{c}\text { Primer: HEMA, PAMA, GPDM, polyalkenoic acid. } \\
\text { Adhesive: Bis-GMA, HEMA, EMAB, polyalkenoic acid copolymers }\end{array}$ & $\begin{array}{c}\text { Primer: } 2 \mathrm{AB} \\
\text { Adhesive: } 3 \mathrm{NL}\end{array}$ \\
Adper Single Bond 2** & Bis-GMA, HEMA, dimethacrylates, polyalkenoic acid, initiators & 4BC \\
AdheSE*** & Dimethacrylate, phosphonic acid acrylate, initiators and & Primer: F35621 \\
& stabilizers, HEMA, silicon dioxide & Adhesive: F35219 \\
Adper Prompt** & Methacrylate phosphoric ester, stabilizers, \\
& parabeno, fluoride complexes, initiators & 187204
\end{tabular}

*Informed by the manufacturers; **=3M/ESPE, St. Paul, MN, USA; ***= Ivoclar/Vivadent, Liechtenstein. 
$\mathrm{mm}$ height; $3 \mathrm{~mm}$ diameter). The composite resin cylinders were built with three 2-mm-thick increments. Each increment was light-cured for $40 \mathrm{~s}$ using a visible light-curing unit (Clean Line Light 2000 n 04344, São Paulo, SP, Brazil), with intensity of $500 \mathrm{mw} / \mathrm{cm}^{2}$, checked with a curing radiometer (Demetron Research Corp., Orange, CA, USA). Thereafter, all the specimens were stored in distilled water in a biological autoclave (ECB 1.3, Odontobras, Ribeirão Preto, SP, Brazil) at $37^{\circ} \mathrm{C}$ for $24 \mathrm{~h}$ or 6 months.

After the storage periods, the specimens were taken to an universal testing machine (Kratos K2000 Equip. Ind. Ltda. / N. M98D301, São Paulo, SP, Brazil), and tested in shear strength at a crosshead speed of 0.5 $\mathrm{mm} / \mathrm{min}$. SBS data were obtained in $\mathrm{kgf}$, transformed into MPa and analyzed stastically by ANOVA and F test at a significance level of $5 \%$.

\section{RESULTS}

The following descriptive statistics was obtained, for the data from the shear test, as shown in Table 2. By the $p$ values obtained from the F test (ANOVA), the hypothesis of equality among the groups with regard to the mean SBSs was rejected. Analysis by Turkey's pairwise comparison test showed statistically significant difference $(\mathrm{p}<0.05)$ between self-etching and etch-andrinse adhesive systems in the 24 -h storage period. In the 6-month period, significant difference $(\mathrm{p}<0.05)$ was found between $\mathrm{AD}$ and $\mathrm{AP}$, but no significant difference ( $p>0.05$ ) was detected between ASBMP and ASB2.

The mean SBSs were higher $24 \mathrm{~h}$. The etch-andrinse systems had significantly higher $(\mathrm{p}<0.05)$ mean SBSs than the self-etching systems at both periods.

Table 2. Mean shear bond strength (MPa) for each adhesive system after short-tem and long-term storage periods.

\begin{tabular}{|c|c|c|}
\hline Material & $24 \mathrm{~h}$ & 6 months \\
\hline ASB Multi Purpose* & $10.03 \pm 3.78 \mathrm{a}$ & $4.05 \pm 0.98 \mathrm{a}$ \\
\hline Adper Single Bond 2* & $6.10 \pm 2.67 \mathrm{a}$ & $5.05 \pm 1.10 \mathrm{a}$ \\
\hline AdheSE** & $1.89 \pm 0.87 \mathrm{c}$ & $1.37 \pm 0.64 b$ \\
\hline Adper Prompt** & $3.41 \pm 1.56 \mathrm{c}$ & $2.77 \pm 0.61 \mathrm{c}$ \\
\hline
\end{tabular}

Different letters in the rows indicate statistically difference at $5 \%$. $*=$ Etch-and-rinse and $* *=$ Self-etching adhesive system.

\section{DISCUSSION}

The effect of water on the degradation process of adhesive systems is an important factor to be assessed. Slow water absorption by the constituents of the adhesive systems could contribute to the degradation of the adhesive interface. Some authors have found a significant reduction on resin-dentin bond strength after 6 months of storage in water $(11,12)$. Studies on the degradation of bond strength as a function of the system and storage time have claimed that incomplete penetration of the adhesive into the demineralized collagen network could result in a thin porous zone between the hybrid layer and the unaltered dentin $(13,14)$.

SEM and TEM (15) investigations of collagen fiber network after storage in water had demonstrated that the top of the hybrid layer contained disorganized collagen fibrils coming from the smear layer, which were degraded at longer periods. The intact fibrils that had been demineralized below the smear layer were not denatured during acid etching. The authors theorized that the collagen fibers could be structurally unstable, contributing to poor resin infiltration, or loss of this protection within the hybrid layer in the course of time, because these fibers being unprotected within the hybrid layer are responsible for compromising the longevity of restorations. The presence of these fibers could be avoided by means of treatment with EDTA, which provides a better preservation of the collagen mesh after demineralization (16).

The results of this study showed significant differences when the bond strengths of etch-and-rinse and self-etching adhesive systems were compared as for the storage times. ASBMP had its bond strength decreased, though without significant difference between the periods. These results are consistent with those of previous studies $(17,18)$.

The strong interaction observed for ASBMP, as regards storage times can perhaps be explained by the formulation of this system, which has a water-based solvent in its composition. It is known that after demineralization, the collagen fibrils must remain expanded, preserving the interfibrilar spaces for infiltration of the adhesive agent. This is achieved by using the wet technique, but the removal of water could occur due to the dehydration caused by the chemical solvent itself, which rapidly mixes with the water in the dentin substrate, removed with evaporation (9). For the 
described process occurs, an interval of waiting is required. However, the time recommended by the manufacturer is insufficient for allowing complete evaporation of the solvent, particularly because, differently from acetone and ethanol, water has a much slow evaporation process, which probably led to a reduction in bond strength after storage in water for a long period.

There was no significant difference for ASB2 when stored for either the short- or long-term period, demonstrating a favorable behavior and a potential preservation of bond stability in a degrading medium. This result can be explained by the fact that this material contains ethanol as a solvent, which favors its use in the wet bonding technique, and by the active form of application, since this organic solvent rapidly mixes with water and facilitates evaporation within the time recommended by the manufacturer (19).

From the results obtained in this study, it may be assumed that the application of a hydrophobic layer after using a hydrophilic primer is not much relevant, if one considers that ASB2 etch-and-rinse system and AP self-etching system presented a stable behavior over time and seemed not to undergo chemical degradation, even after being stored in water for a long time.

On the other hand, an increase in the thickness and compactness of the smear layer has been directly related to lower bond strength values obtained by selfetching adhesive systems, especially 2-step materials (5), which could have contributed to the low SBS observed in this study for AD.

Low bond strength values have been reported for for AP, especially to dentin, with a large number of failures in a previous study (20). In the present study, as far as the mean SBSs of the self-etching adhesive systems are concerned, AP had numerically higher SBS than $\mathrm{AD}$, this difference being statistically significant after 6 months of water storage. Perhaps, this result might be explained by the hydrogenionic potential of this material ( $\mathrm{pH} 0.4$ to 0.8 ), which is considered a strong self-etching system. This acidity results in a rather deep demineralization effect, similar to that produced by phosphoric acid. However, a specific demineralization does not seem to be a determinant factor for bond strength to dentin, but rather the relationship of depth of demineralization and impregnation of the adhesive, since hybrid layer formation does not require deep demineralization (1).

Due to their hydrophilic characteristics, the self- etching systems tend to present potential degradation in the course of time, as water plays a key role in polymer degradation $(9,10)$. In this study, this type of behavior seemed to have contributed to the mean SBSs obtained, particularly for AD.

In view of the issues discussed herein, it is clear that the etch-and-rinse and self-etching adhesive systems still raise several questions. Further research is needed to assess other variables that interfere directly on bond stability. Based on the obtained results, it may be concluded that the tested etch-and-rinse adhesive systems had a better performance in terms of bond durability over time than the self-etching adhesive systems.

\section{RESUMO}

O objetivo deste estudo foi avaliar, in vitro, a influência do armazenamento em meio degradante a curto e longo prazo sobre os sistemas adesivos: Adper Scotch Bond Multi Purpose (ASBMP); Adper Single Bond 2 (ASB2); AdheSe (AD) e Adper Prompt (AP). Oitenta dentes bovinos foram selecionados e aleatoriamente divididos em 8 grupos $(\mathrm{n}=10)$. Após o tratamento da superfície, cilindros de resina composta Tetric Ceram foram confeccionados utilizando uma matriz metálica bipartida. Os espécimes foram armazenados em água destilada a $37^{\circ} \mathrm{C}$ por $24 \mathrm{~h}$ ou 6 meses. Após estes períodos, o teste de cisalhamento foi realizado em uma máquina de ensaio universal $(0,5 \mathrm{~mm} / \mathrm{min})$. Os resultados em MPa foram submetidos à ANOVA e ao teste $\mathrm{F}$ em nível de significância de 5\%. O ASBMP $(10,03 \pm 3,78)$ e ASB2 $(6,10 \pm 2,67)$ não apresentaram diferenças estatisticamente significativas entre os tempos de armazenamento. Os autocondicionantes não diferiram estatisticamente no período de $24 \mathrm{~h}$, mas houve diferença para o $\mathrm{AD}(1,37 \pm 0,64)$, quando armazenado por 6 meses. Esses adesivos obtiveram valores inferiores nos períodos de avaliação em relação aos convencionais. Os adesivos convencionais mostraram melhor desempenho laboratorial que os autocondicionantes em termos de durabilidade da adesão ao longo do tempo.

\section{REFERENCES}

1. Van Meerbeek B, De Munck J, Yoshida Y, Inoue S, Vargas M, Vijay $\mathrm{P}$, et al. Buonocore memorial lecture. Adhesion to enamel and dentin: current status and future challenges. Oper Dent 2003;28:215-235.

2. Inoue S, Vargas MA, Abe Y, Yoshida Y, Lambrechts P, Vanherle $\mathrm{G}$, et al. Microtensile bond strength of eleven contemporary adhesives to dentin. J Adhes Dent 2001;3:237-245.

3. Van Meerbeek B, Perdigão J, Lambrechts P, Vanherle G. The clinical performance of adhesives. J Dent 1998;26:1-20.

4. Borges GA, Spohr AM, Oliveira WJ, Correr-Sobrinho L, Correr AB, Borges LH. Effect of refrigeration on bond strength of self-etching adhesive systems. Braz Dent $\mathrm{J}$ 2006;17:186-190.

5. Koibuchi H, Yasuda N, Nakabayashi N. Bonding to dentin with a self-etching primer: the effect of smear layers. Dent 
Mater 2001;17:122-126.

6. Pashley DH, Carvalho RM, Sano H, Nakajima M, Yoshima M, Shono Y. The microtensile bond test: a review. J Adhes Dent 1999;1:299-309.

7. Ye Q, Park JG, Topp E, Wang Y, Misra A, Spencer P. In vitro performance of nano-heterogeneous dentin adhesive. $\mathrm{J}$ Dent Res 2008;87:829-833.

8. Sano H, Takatsu T, Ciucchi B, Horner JA, Matthews WG, Pashley DH. Nanoleakage: leakage within the hybrid layer. Oper Dent 1995;20:18-25.

9. Carvalho RM, Chersoni S, Frankenberger R, Pashley DH, Prati C, Tay FR. A challenge to the conventional wisdow that simultaneous etching and resin infiltration always occurs in self-etch adhesives. Biomater 2004;26:1035-1042.

10. Tay FR, Pashley DH. Water-treeing - A potential mechanism for degradation of dentin adhesives. Am J Dent 2003;16:612.

11. Hashimoto M, Ohno H, Sano H, Tay FR, Kaga M, Kudou Y, et al. Micromorphological changes in resin-dentin bond after 1 year of water storage. J Biomed Mater Res 2002;63:306-311.

12. Giannini M, Seixas CA, Reis AF, Pimenta LAF. Six-month storage-time evaluation of one-bottle adhesive systems to dentin. J Esthet Restor Dent 2003;15:43-48.

13. Armstrong SR, Vargas MA, Chung I, Pashley DH, Campbell JA, Laffoon JE, et al. Resin-dentin interfacial ultrastructure and microtensile dentin bond strength after five-year water storage. Oper Dent 2004;29:705-712.
14. Van Meerbeek B, De Munck J, Yoshida Y, Inoue S, Vargas M, Lambrechts P. Micro-tensile bond strength of 4 total-etch adhesives to dentin after 4-year water storage. J Dent Res 2002;81:138.

15. Yang B, Adelung R, Ludwig K, Bobmann K, Pashley DH, Kern M. Effect of structural change of collagen fibrils on the durability of dentin bonding. Biomater 2005;26:5021-5031.

16. Osorio R, Erhardt MCG, Pimenta LAF, Osorio E, Toledano M. EDTA treatment improves resin-dentin bonds' resistance to degradation. J Dent Res 2005;84:736-740.

17. Konno AN, Sinhoreti MA, Consani S, Correr Sobrinho L, Consani RL. Storage effect on the shear bond strength of adhesive systems. Braz Dent J 2003;14:42-47.

18. Hashimoto M, Ohno H, Kaga M, Endo K, Sano H, Oguchi H. In vivo degradation of resin-dentin bonds in human over 1 to 3 years. J Dent Res 2000;79:1385-1391.

19. Souza-Zaroni WC, Seixas LC, Ciccone-Nogueira JC, Chimello DT, Palma-Dibb RG. Tensile bond strength of different adhesive systems to enamel and dentin. Braz Dent J 2007;18:12428.

20. De Munck J, Van Meerbeek B, Yoshida Y, Inoue S, Vargas M, Suzuki K. Four-year water degradation of total-etch adhesives bonded to dentin. J Dent Res 2003;82:136-140.

Accepted July 21, 2008 